\title{
WHY IS SAUDI ARABIA'S EFL TEACHER ATTRITION RATE SO HIGH, AND WHAT CAN BE DONE TO STEM THE TIDE OF TRANSIENT EFL TEACHERS?
}

\author{
Andy Pacino ${ }^{1}$ (D) Faiza Qureshi ${ }^{2}$ iD \\ ${ }^{1}$ M. Ed, MA (TESOL). ELT Central, UK \\ ${ }^{2}$ M.Ed. Murdoch University, Dubai, United Arab Emirates.
}

\section{ARTICLE INFO}

Recieved: 03 September 2021 Revised: 22 October 2021

Accepted: 03 November 2021

Keywords:

EFL, Teacher Attrition Rate,

Saudi Arabia,

Transient Teachers,

Higher Education

Corresponding Author:

Andy Pacino

Email: andypac@gmail.com Copyright (C) 2021, Middle Eastern Journal of Research in Education and Social Sciences.

This work is licensed under the Creative Commons Attribution International License (CC BY 4.0) http://creativecommons.org/licenses/ by/4.0/
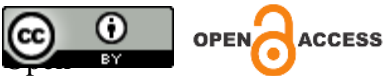

\begin{abstract}
Purpose: This article is focused on the high attrition rate of English as a Foreign Language (EFL) teachers in the Kingdom of Saudi Arabia. It looks into the possible reasons that cause teachers to leave the country or the profession after spending a short time there, based on data collected from EFL teachers from across the Kingdom.

Approach/Methodology/Design: This study used a mixed methods enquiry design, initially carried out through semi-structured interviews in a qualitative manner. Five teachers who worked in various higher education institutes across the Kingdom were interviewed and questioned about various aspects of their professional life as a teacher in the KSA. Those interviews were subsequently analysed to create questionnaires which were then administered to a sample of 20 teachers. The returned questionnaires were analysed and reported in numerical charts for ease of visual clarity. The lower the figure, the less motivation or satisfaction there was in the field.

Findings: NEST attrition rates in Saudi Arabia are abnormally high due to a serious lack of cultural training by management and/or provider, poor induction once a teacher arrives in country and culture. NNEST attrition rates are more aligned to professional reasons, as they feel they are treated poorly by comparison with their NEST counterparts: lower wages, fewer promotion opportunities, not being taken as seriously by students and employers, and sudden discontinuance of contracts among the main reasons for NNESTs leaving their posts.

Practical Implications: The study makes suggestions as to how teachers' needs might be addressed in order to reduce the outflow of professional teachers from Saudi Arabia.

Originality/value: There is very little continuity in teaching due to large numbers of teachers exiting the Kingdom after a very short period of time. NEST attrition rates in Saudi Arabia are abnormally high due to a number of reasons.
\end{abstract}

\section{INTRODUCTION}

Saudi Arabia has made major investments into its higher education (HE) system over the past three or four decades, and has recognised the importance of providing its youth with a standard of education that will secure the country's future with bright innovators and business leaders to 
compete on the world stage (Yusuf, 2014). The realisation that the English language is of paramount importance has not been lost on the country's HE experts, and large amounts of money have been spent on providing college and university students with an opportunity to learn English in order to communicate their business discussions and realise their potential.

This means offering an education that will raise the language capabilities of its youth, which includes English language skills (Yusuf, 2014). To achieve these ends, the Kingdom's Government also offers some of the highest wages in the world for EFL teachers. Coupled with a low cost of living, this makes an attractive proposition for expatriate English language teachers - both natives and non-natives speakers of the English Language - to work in the Kingdom. However, as both experience and research shows, attrition rates within the profession are extremely high (Alhamad, 2018).

In the main, there are three types of expatriate EFL teachers that work in the Kingdom. The first of the three categories are the Native English Speaking Teachers (NESTs) who tend to be the savers/travellers from countries such as the United Kingdom, Australia, Ireland, Canada and the USA. They spend a short number of years in the country earning enough to top up a bank account that will help them cover future money concerns, or to fund travels across more poorly paid countries. Teachers often use teaching English as a means to gain more worldly experience (Stainton, 2017; Ahmad et el., 2017). The second category is the Native English Speaking Teachers who are religious converts (also NESTs) who want to live in a country that has significance based on their religious beliefs. Finally, there are the Non-Native English-Speaking Teachers (NNESTs) who leave their native countries for better earning potential, and while they tend to be more vocationally motivated (Pacino, 2016), they are more often than not paid much less than their NEST counterparts (Louber, 2015).

Even with such a high potential for earning and a low cost of living, teachers still, year upon year, leave the country en masse after only a short period of teaching. This leaves the Kingdom with both a consistency problem, and a merry-go-round training schedule for both management and new teachers in a rapidly changing and challenging environment. As this continual change is not conducive to student support, development and education, this study aims to find what are the causes behind so many teachers arriving and subsequently leaving their posts, and what could be done to halt the exodus (Alhamad, 2018).

\section{Significance of the study}

Although the Saudi Arabian Government has injected vast amounts of money into and across all levels of its education system over the past thirty years or so, teacher retention remains a serious problem. For any kind of stable teaching and learning pattern to emerge, there must also be some kind of quality and consistency in both the stream of education and in the teachers who deliver it. There is a wide gap in research that addresses where that consistency is lacking, and although there are a number of papers relating to some areas of teacher attrition in the Kingdom of Saudi Arabia, the researchers identified a distinct lack of such in the particular areas in which this study will concentrate.

This study is twofold and sets out to achieve the following aims: the first is to explore past academic research to find commonalities with areas of dissatisfaction and demotivation that 
lead to so many teachers leaving their positions, and secondly, it explores areas where support to teachers could be improved, and to offer possible solutions to address such shortcomings.

\section{LITERATURE REVIEW}

Teacher attrition rates are very high in the Kingdom of Saudi Arabia, and managers face difficulties keeping hold of their best talent (Alhamad, 2018). Research has shown that some of the reasons for this are; inadequate high-level support, company policies, low employment values and poor use of the teachers' time while they are on the job (Brittiler \& Thabet, 2015), as well as poor administration and management (Mosadegh \& Yarmohammedian, 2006). Other reasons included demanding authority figures, lack of monetary resources, poor training schedules and ineffective response to complaints or requests, and poor treatment of NNESTs (Alzaidi, 2007). Further, additional factors include a lack of support in teaching and a serious lack of career progression opportunities (Pacino, 2016). While it seems obvious that working conditions, unfulfilled promises of standard working hours, a lack of communication and disparity in salary would be a sign of poor management and certainly not a motivator, these were very real issues that led to objections and dissatisfaction among teachers (Pacino, 2016). Worryingly, Hanneman's study found underpayment, overwork and trying conditions in the workplace were the major reasons teachers found it difficult to stay focussed and deliver quality classes (2014).

Neither teachers nor learners benefit from substandard facilities or a lack of training or professional development, yet both battle against such on an all too regular basis (Ashraf, 2015). Problems often arise for novice teachers from the very beginning of their careers, and this leads to high attrition rates (Brighton, 1999). These issues range from poor training and an inability to cope with demanding delivery targets, poor preparation in training, wide differentiation in class and a feeling of hopelessness due to the unachievable expectations of senior management or institution (Alhamad, 2018). Another staggering figure Alhamad's study revealed was that 100 per cent of teachers reported they received no support or training whatsoever directly from their principals or management (2018). Also in Alhamad's study, more than 80 per cent of teachers felt as though they had been thrown in at the deep end without support, and felt that they were not well enough equipped to handle the day-to-day workings of a class (2018).

Nor were they adequately supplied with material. They had little time to become familiar with the curriculum or even the chance to settle in before they were thrown headlong into classes, having to rely on more experienced (though possibly not particularly good) teachers for support rather than the management providing it (Alhamad, 2018). Added to this are culture shocks that the conservatism of the country has on newly migrated novice teachers. These stark and often challenging aspects can be a heavy burden to bear for Western teachers and a great many teachers are unable to acclimatise to these conditions. This is further reflected in abnormally high teacher attrition rates (Shah et al., 2013).

Teachers tend to enter their profession to genuinely make their students' learning experiences better, rather than for the financial reward (Pacino, 2016). However, when these professionals seem to be thwarted from many angles; disparity in wages and discrimination (NNESTs), poor student discipline, lack of support with physical material provision, poor training schedules, 
exclusion from classroom decisions such as which material and methods to use and unbalanced criticism/praise, it is hardly surprising many choose to abandon either the country or the profession altogether (Dörnyei \& Ushioda, 2011). One of the most complained about factors with teachers in Saudi Arabia is job satisfaction. When a teacher is happy in his work, he will often go the extra mile and work for a lower wage, though having said that, when they are unhappy they tend to deliver sloppy teaching (Tshannen-Moran et al., 1998).

If Saudi's EFL teacher attrition rate is to either steady or decrease, there must be recognition of the importance of teachers and compulsory implementation of vocational training and the integration of technology (Khan, 2017). One way of avoiding resentment and raising the feeling of worth and appreciation would be to offer and show support in actions as well as words (Periansya, 2017). While there were a large number of schools and higher education institutions that do not cater for extracurricular activities or training, many teachers and students recognised that get-togethers would be an excellent way of providing morale boosting and a happier, more contented staff (Jamjoon, 2012).

There is clearly a case for looking further into this problem with a deeper study into demoralisation, as while some teachers still feel motivated, it appears it is more to do with factors such as finance or beliefs rather than furthering their vocational skills. If Saudi Arabia is to truly transform its education in EFL, steps must be taken to find the right teachers who are willing to stay the distance and gain professional experience. It should also ensure that HE providers deliver on their promises for delivering quality training and professional development for their teachers.

\section{METHODOLOGY AND PROCEDURES}

This study used a mixed methods enquiry design. This was initially carried out through semistructured interviews in a qualitative manner. In order to form a questionnaire, a number of semi-structured interviews were held to find the most pressing concerns among teachers within the Kingdom. Five teachers who worked in various higher education institutes across the Kingdom were interviewed and questioned (Appendix A) about various aspects of their professional life as a teacher in the KSA. Those interviews were subsequently analysed to create questionnaires (Appendix B), which were then administered to a more significant number (20) of teachers who worked across 12 cities in the Kingdom. This would provide quantitative measurable information. The feedback from the initial interviews was extremely negative, as had been both authors' experience from working in the KSA, therefore, although the questions may appear negative, this was due solely to the aforementioned feedback, and there was the opportunity for motivated and satisfied teachers to provide high marks should they have felt it was appropriate.

The subsequent questions were then broken into six subject areas; leadership and management, institution, students and teaching, peers and socio-cultural. The initial phase was conducted using a set of loosely based questions around management, source materials, motivation, job satisfaction and teaching generally in a Saudi context, and the responses were subsequently used to form a set of 102 structured questions that measured firstly, motivation and secondly, satisfaction using a Likert scale between 1 and 5. The lower the number, the less motivated or satisfied the teacher was $(1=$ very demotivated, $2=$ demotivated, $3=$ no opinion, $4=$ motivated, 
$5=$ very motivated $)$ and $(1=$ very dissatisfied, $2=$ dissatisfied, $3=$ no opinion, $4=$ satisfied, $5=$ very satisfied). Each increment in number represents a $5 \%$ degree of (de)motivation or (dis)satisfaction. For example, if all 20 teachers were very satisfied that their management did not inflate grades (Q10), there would be a mark of 20 (x 5), which would equal a score of $100 \%$ motivation/satisfaction figure, however, the opposite would mean $100 \%$ demotivation/dissatisfaction figure.

\section{Ethics}

Ten of the quantitative participants were not known to the researchers and had never come into contact with them on either a professional or personal level. All participants were informed that their identities would remain anonymous, especially given the kind of research that required information about their job motivation, satisfaction and working conditions (Seidman, 2006, p.123). Information sheets and consent forms were also provided to each of the participants to inform them of the aims of the research, that all data collected would remain anonymous, and that their identities would not be revealed. Further, the consent form also informed them that their participation was entirely voluntary and they could choose to withdraw up till one month after the completion of the research. The participants were given pseudonyms to further protect their identities during the data analysis stage. All the interviews were conducted and transcribed by the researchers and all the recorded interviews were stored safely on a laptop computer while the data was analysed. Similarly, only the researchers accessed the questionnaire information

\begin{tabular}{|c|c|c|c|c|c|c|}
\hline \multirow{2}{*}{$\begin{array}{l}\text { Q No } \\
>\text { to }<\end{array}$} & Teachers' reasons for $\&$ levels of motivation & \multicolumn{5}{|c|}{ Motivation \% to work in KSA } \\
\hline & Very demotivated, demotivated, no opinion, motivated very motivated > & VD & D & No & $\mathbf{M}$ & VM \\
\hline 19 & $\begin{array}{l}\text { Management is clear. Teachers are given concrete instructions. Information on } \\
\text { piolicies is readily available in adequate time for term start. }\end{array}$ & 75 & 5 & 20 & 0 & 0 \\
\hline 10 & Grades of the students & 50 & 30 & 20 & 0 & 0 \\
\hline 17 & The management's honesty with the teachers & 50 & 25 & 25 & 0 & 0 \\
\hline 9 & Management's deling with complaints made by the students against the teachers. & 55 & 20 & 15 & 5 & 5 \\
\hline 15 & Favouritism amongst teachers & 50 & 25 & 15 & 10 & 0 \\
\hline 13 & Leadership/management get due credit & 35 & 45 & 15 & 5 & 0 \\
\hline 2 & Supervision & 35 & 40 & 20 & 5 & 0 \\
\hline 7 & Supervisor's interpersonal relationship with the teachers & 45 & 25 & 20 & 5 & 5 \\
\hline 1 & Understanding of the local culture by the management & 30 & 35 & 35 & 0 & 0 \\
\hline 18 & Meetings with the management & 45 & 35 & 20 & 5 & 0 \\
\hline 5 & Supervisor's knowledge of his/her job & 40 & 25 & 25 & 5 & 0 \\
\hline 8 & Dealings with the students by the management & 40 & 40 & 0 & 15 & 5 \\
\hline 16 & Leadership/management get due credit & 40 & 20 & 35 & 20 & 0 \\
\hline 14 & Heads' careerism & 30 & 35 & 30 & 0 & 5 \\
\hline 6 & Delegation of work & 35 & 25 & 25 & 15 & 0 \\
\hline 12 & Management direction & 30 & 35 & 25 & 5 & 5 \\
\hline 4 & Support from the supervisor & 35 & 30 & 15 & 15 & 5 \\
\hline 11 & Management organisation & 35 & 25 & 20 & 20 & 0 \\
\hline 20 & Mentoring provision for the teachers & 30 & 30 & 25 & 10 & 5 \\
\hline \multirow[t]{5}{*}{3} & Feedback from the supervisor & 25 & 30 & 30 & 15 & 0 \\
\hline & possible score & 2000 & 2000 & 2000 & 2000 & 2000 \\
\hline & percentage of (de)motivation of teacher & 40 & 29 & 21.75 & 7.5 & 1.75 \\
\hline & rounded figure & 40 & 29 & \begin{tabular}{|l|l}
22 \\
\end{tabular} & 8 & 2 \\
\hline & & VDM & $\mathrm{DM}$ & NO & $\mathrm{M}$ & $\mathrm{VM}$ \\
\hline $\mathrm{Mid} \mathrm{d}$ & 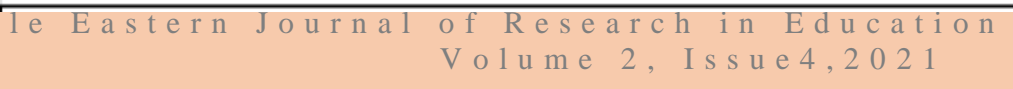 & nd $S$ & oc ia & $1 \mathrm{Sci}$ & $10 \mathrm{nc}$ & \\
\hline
\end{tabular}


and copies.

Fig 1. Leadership/Management motivational responses (Pacino, 2016).

\section{RESULTS AND DISCUSSION}

The returned questionnaires and figures were then analysed and reported in numerical charts for ease of visual clarity. The lower the figure, the less motivation or satisfaction there was in the field. These figures would provide a visual depiction of areas where there is most concern. The primary goal was to find the main reasons teachers find it difficult to stay working in Saudi Arabia. The factors that caused most concern for teachers was upper management and its continual failure to provide; concrete instructions, general clarity about tasks and expectations, support in areas of professional development, resources, transparency with teachers, support against student complaints without thorough investigation, proper leadership and unbiased treatment of all teachers. Following these complaints were; a lack of understanding of the local culture, incompetent supervision and little or no interpersonal connection.

Added to this was the fact that teachers felt they could not approach management with their concerns, and therefore felt there was no point in doing so. This was the major factor in both motivation and job and satisfaction for teachers, which points to them having little faith in matters changing or improving. Therefore, this area, and the most concerning questions (Qs 1 to 20 ), and will be the main focus of this paper, while questions 21 to 60 will supply figures regarding the motivation and satisfaction that working for a well managed institution provides. Figures (Fig. 1) showed a sustained trend of demotivation among teachers in the country. Heading the table were issues of poor management and leadership. The three worst-performing categories (leadership and management) were management ambiguity (Q19, 29\%), student grade inflation (Q10, 34\%) and management dishonesty (Q17, 35\%). Not a single teacher felt motivated by any of these aspects of management. Only one teacher felt his institution fully supported him (Q4) while $65 \%$ of teachers felt dissatisfied with such. Looking at the whole section, it is plainly obvious that there is huge room for improvement in management techniques and administration. The highest figure for the very motivated section, of a possible score of 2,000 , the figure reached 35 , which converts to only $1.75 \%$ very satisfied rating, with almost $70 \%$ of teachers dissatisfied with their management and $21.75 \%$ having no opinion.

Satisfaction in these areas drew only slightly better responses with ambiguity and grade inflation being the two main areas for concern, and teacher favouritism accounting for a $75 \%$ (Fig. 2) dissatisfaction rate (Q15). Both charts demonstrate very similar findings for each of the questions. Even the highest scoring point (teacher feedback from supervisor - Q3) failed to reach even a 50\% approval rate, without a single teacher said they were very satisfied. In fact, in all twenty points, from a possible 'very satisfied' rating of 2,000 it reached a score of only 55, which translates to $2.75 \%$ satisfaction. 


\begin{tabular}{|c|c|c|c|c|c|c|}
\hline \multirow{2}{*}{$\begin{array}{l}\text { Q No } \\
>\text { to }<\end{array}$} & \multirow{2}{*}{$\begin{array}{c}\text { Teachers' reasons for } \& \text { levels of satisfaction } \\
\text { Very dissatisfied, dissatisfied, no opinion, satisfied, very satisfied }>\end{array}$} & \multicolumn{5}{|c|}{ Current \% Job satisfaction } \\
\hline & & VD & DS & NO & $\mathbf{S}$ & VS \\
\hline 19 & $\begin{array}{l}\text { Management is clear. Teachers are given concrete instructions. Information on } \\
\text { piolicies is readily available in adequate time for term start. }\end{array}$ & 75 & 5 & 15 & 5 & 0 \\
\hline 10 & Grades of the students & 45 & 35 & 20 & 0 & 0 \\
\hline 15 & Favouritism amongst teachers & 55 & 20 & 20 & 5 & 0 \\
\hline 17 & The management's honesty with the teachers & 40 & 35 & 20 & 5 & 0 \\
\hline 18 & Meetings with the management & 40 & 35 & 15 & 10 & 0 \\
\hline 9 & Management's dealing with complaints made by the students against the teachers. & 50 & 20 & 15 & 10 & 5 \\
\hline 16 & Leadership/management get due credit & 45 & 15 & 35 & 5 & 0 \\
\hline 2 & Supervision & 40 & 25 & 25 & 10 & 0 \\
\hline 13 & Leadership & 35 & 40 & 10 & 15 & 0 \\
\hline 1 & Understanding of the local culture by the management & 35 & 35 & 20 & 5 & 5 \\
\hline 4 & Support from the supervisor & 54 & 25 & 1 & 15 & 5 \\
\hline 5 & Supervisor's knowledge of his/her job & 40 & 25 & 20 & 15 & 0 \\
\hline 6 & Delegation of work & 45 & 15 & 20 & 20 & 0 \\
\hline 7 & Supervisor's interpersonal relationship with the teachers & 45 & 20 & 15 & 15 & 5 \\
\hline 14 & Heads' careerism & 25 & 45 & 25 & 0 & 5 \\
\hline 11 & Management organisation & 35 & 35 & 10 & 15 & 5 \\
\hline 20 & Mentoring provision for the teachers & 50 & 100 & 15 & 20 & 5 \\
\hline 8 & Dealings with the students by the management & 35 & 35 & 5 & 15 & 10 \\
\hline 12 & Management direction & 30 & 35 & 20 & 5 & 10 \\
\hline \multirow[t]{5}{*}{3} & Feedback from the supervisor & 30 & 15 & 35 & 20 & 0 \\
\hline & possible score & 2000 & 2000 & 2000 & 2000 & 2000 \\
\hline & Percentage & 42 & 26.25 & 18.5 & 10.5 & 2.75 \\
\hline & Rounded fgure & 42 & 26 & 19 & 11 & 3 \\
\hline & & VD & DS & NO & $\mathrm{S}$ & VS \\
\hline
\end{tabular}

Fig 2. Leadership/Management satisfaction responses (Pacino, 2016).

For all the expense Saudi Arabia has poured into the area, HE falls drastically short on providing the kind of support the Kingdom's present and future teachers need. Indeed, both Nolan (2012), and Al Asmari (2015) revealed many challenges that have to be addressed before progress can be made. Among them a shortage of audio visual aids, too large class sizes, poor Internet coverage, a shortage or complete lack of even the most basic materials such as pens and books, and existing curricula (Yusuf, 2014; Al Asmari, 2015).

Further problems include facilities that suffer from a distinct lack of necessary material and equipment (Al Sharari, 2016). While novice ex-pat teachers expect to receive training and be appropriately embedded in a system, they feel continually let down by out-dated and inappropriate curricula and little classroom support or offer of mentoring (Mansour et al., 2013; Al Sharari, 2016; Bhola, 2019). This presents a serious problem, certainly when considering the Kingdom has invested such large sums in English language education. Students' inability in English, their apathy, or their disinterest in their subjects accounted for $73 \%$ of teachers stating this aspect led to demotivation and dissatisfaction with their work, and those who did stay in the country were motivated solely by the amount of money they could earn (Pacino 2016). 
The importance of training for all teaching staff - Arab and Westerner - was recognised as early as the 1980s when, with the advancement of globalisation, English language gained greater importance for the Saudi Government, who realised the level of English spoken for travel, science, diplomatic relations and large scale business was crucial to the country's standing on the world stage as a major business player (Adelman \& Lustig, 1981). While this was true for the Kingdom, its growth and importance also indicated a greater influence of the Arabic language and culture on both a global scale and for those arriving to work in the country, where speaking the language makes creating friendships much easier (Cooper, 1980). While many companies offer language training, many teachers do not take these up (Ashraf, 2018). Several factors were mentioned that impeded delivery of quality lessons that included a lack of time for preparing classes, a lack of privacy for meetings and little or no professional development sessions (Al Qahtani, 2019). There were few chances for orientation to either the department or the country or introductions to quirks and nuances with the new culture. Leadership skills were also pointed out as being deficient or non-existent that contributed to failing delivery of effective education (Alhammad, 2000; Albatain, 2009).

Problems identified included dissatisfaction, demotivation, a lack of transparency, and poor communication (Al Sharari, 2016; Pacino, 2016). As long as these problems continue, Saudi Arabia will see its own students falling behind those of other countries and their education systems (Shannag et al., 2013). The distinct lack of management technique in both supervisory or management adds to the general slip-shod or ad hoc organisation, with few in higher management positions having the necessary skills to perform the tasks with any sort of competence (Almakushi, 2003). While importance is given to the promotion of English in schools and colleges, unless more properly trained and capable teachers are hired current teaching staff will be burdened with longer hours and far more time spent on marking than providing support and guidance for their students: possibly proving to be the proverbial final straw for many students and teachers alike (Heppner, 2007). Inequality with wage structures was also a major complaint from NNESTs, with almost $70 \%$ of respondents to Subbaravalu and Al Kuwaiti's 2018 study stating teachers were not only overworked, but also saw financial reward fall somewhat below their NEST counterparts.

However, more than management and leadership issues were the concerns with poorly run institutions (Fig. 3). This second section, consisting of 40 questions, addressed institutional problems. Once again, there were very few areas within the institutions where teachers were very satisfied. Two of the questions (23; false promises from the institution, and 25; lack of job security) received the lowest score of all, followed very closely by question 26 (29\% - teachers fired on the spot), while the corresponding responses to the institution's effect on job satisfaction revealed similarly depressing figures.

There can be little doubt that teachers who feel unappreciated and undervalued will almost certainly perform to a lower standard than those who are recognised for the work they do and the input they have in the classroom (Abdulkareem, 2015). A failure to address this issue has a very good chance of ending in abject failure (Mansory, 2019), as is the lack of appreciation for a job well done rather than merely heaping criticism on a teacher when something has gone awry (Geiger \& Pivovarova, 2018). Among the many worries for the education departments are problems with discipline, exhausted teachers who are made to work hours well beyond those 
recommended and inefficient learning techniques and procedures (Hattie, 2005; Pedder, 2006), which leads to classes brimming with anxious students (Bahanshal, 2013), and 60\% of one institution's teachers deciding the working environment in Saudi was too much to bear (Bhola, 2019).

\begin{tabular}{|c|c|c|c|c|c|c|}
\hline \multirow{2}{*}{$\begin{array}{l}\text { Q No } \\
>\text { to }<\end{array}$} & \multirow{2}{*}{$\begin{array}{c}\text { Teachers' reasons for } \& \text { levels of (de)motivation (institution) } \\
\text { Very demotivated, demotivated, no opinion, motivated, very motivated > }\end{array}$} & \multicolumn{5}{|c|}{ Current \% Job motivation } \\
\hline & & VDM & DM & NO & $\mathbf{M}$ & VM \\
\hline 21 & Resources and funding allocation & 50 & 20 & 25 & 5 & 0 \\
\hline 22 & Parental involvement & 30 & 20 & 40 & 0 & 10 \\
\hline 23 & Promises kept by the institution & 65 & 30 & 5 & 0 & 0 \\
\hline 24 & Competent and effective institution & 55 & 25 & 15 & 5 & 0 \\
\hline 25 & Job security & 65 & 30 & 5 & 0 & 0 \\
\hline 26 & Short notice contract termination & 65 & 25 & 10 & 0 & 0 \\
\hline 27 & Teachers receive fair warning of contract loss & 45 & 30 & 20 & 5 & 0 \\
\hline 28 & Career progression, advancement or growth & 25 & 35 & 30 & 0 & 0 \\
\hline 29 & CPD opportunities & 35 & 15 & 30 & 15 & 5 \\
\hline 30 & Integration procedure for new teachers & 20 & 40 & 35 & 10 & 5 \\
\hline 31 & Guidance or support for new teachers & 15 & 40 & 45 & 0 & 0 \\
\hline 32 & Orientation for new teachers & 25 & 35 & 30 & 10 & 0 \\
\hline 33 & Living in KSA without family & 35 & 5 & 25 & 10 & 15 \\
\hline 34 & Pay disparities between peer teachers & 45 & 25 & 30 & 0 & 0 \\
\hline 35 & Assessment practices & 35 & 40 & 20 & 5 & 0 \\
\hline 36 & Easier exams for students & 40 & 45 & 15 & 0 & 0 \\
\hline 37 & Teacher recognition & 45 & 35 & 15 & 5 & 0 \\
\hline 38 & Appreciation for teachers' hard work & 45 & 30 & 25 & 0 & 0 \\
\hline 39 & Visa issues & 55 & 20 & 15 & 10 & 0 \\
\hline 40 & Suitable/relevant curriculum & 45 & 30 & 10 & 15 & 10 \\
\hline 41 & Salary & 45 & 10 & 15 & 25 & 5 \\
\hline 42 & Payment of salaries & 25 & 10 & 40 & 15 & 10 \\
\hline 43 & Benefits like health insurance & 40 & 15 & 10 & 35 & 0 \\
\hline 44 & Innovation or improvement & 45 & 20 & 25 & 10 & 0 \\
\hline 45 & Transparency in communication and what they try to achieve & 40 & 35 & 15 & 10 & 0 \\
\hline 46 & Housing allowance/ accommodation problems & 55 & 20 & 25 & 0 & 0 \\
\hline 47 & Eleventh hour culture & 40 & 40 & 5 & 15 & 0 \\
\hline 48 & Culturally relevant teaching material and textbooks & 40 & 35 & 20 & 5 & 0 \\
\hline 49 & The company's spend on resources and facilities & 5 & 20 & 25 & 0 & 5 \\
\hline 50 & Syllabus and learners' level and needs & 60 & 15 & 15 & 10 & 0 \\
\hline 51 & Consistent attendance policy & 40 & 35 & 15 & 1 & 0 \\
\hline 52 & The students are able to keep up with the pacing guide. & 41 & 40 & 20 & 10 & 0 \\
\hline 53 & Placement of students: proficiency and the classes they are placed in & 60 & 50 & 20 & 0 & 0 \\
\hline 54 & Resources & 35 & 25 & 20 & 15 & 5 \\
\hline 55 & Technology for teaching & 40 & 5 & 25 & 20 & 10 \\
\hline 56 & Lack of technical training for teachers & 30 & 20 & 50 & 5 & 0 \\
\hline 57 & Lack of facilities at work & 35 & 25 & 15 & 20 & 5 \\
\hline 58 & Lack of working equipment & 35 & 20 & 30 & 10 & 5 \\
\hline 59 & The work environment does not facilitate teaching & 50 & 15 & 20 & 10 & 0 \\
\hline \multirow[t]{5}{*}{60} & Teachers are treated disrespectfully at work & 55 & 25 & 15 & 5 & 0 \\
\hline & possible score & 4000 & 4000 & 4000 & 4000 & 4000 \\
\hline & percentage of (de)motivation of teacher & 41.75 & 26.375 & 21.75 & 7.625 & 2.25 \\
\hline & rounded figure for $\%$ of (de)motivation & 42 & 26 & 22 & 7 & 2 \\
\hline & & VDM & $\mathrm{DM}$ & NO & M & VM \\
\hline
\end{tabular}

Fig 3. Institution job motivational responses (Pacino, 2016). 
The focus on institutional inadequacies were spread over 40 aspects, and once again almost every area suffered low scores: the very satisfied and motivated columns both totalled less than $3 \%$ overall, which demonstrates the amount of room there is for improvement in these areas. Again, while the lack of facilities or functioning equipment scored low, they were certainly not the biggest areas for concern. The lack of recognition for teachers, the fact that students were incapable of dealing with the standard of language or learning expected of them, and the differentiation in class were also problems that needed addressing. Other complaints included that textbooks were inappropriate for the setting, there was a culture of eleventh hour operating procedures, a refusal to spend budgets when there was a clear need (and ability to provide such material), institutions allowing parental involvement, and the failure to adhere to absenteeism and lateness rules meant expected levels of learning were impossible to reach (Pacino, 2016).

Heppner's study also revealed that large classes are the standard rather than the exception to the rule (2007), further supporting this is Bahanshal's 2013 study that revealed teachers admitted to struggling - along with their students - to find ways to best serve the large classes with anything from 30 to 45 students sitting at one time, with all parties leaving the class feeling tired and worn out. This demonstrates the real problem of plus-sized classrooms, and a failure to deliver educational services (Omar, 2016). Hughes' study found that poor salary, poorly behaved students, limited parental involvement and a lack of professional recognition were a major cause of teachers leaving either the post or the profession completely (2012), and the above figures support that. Other complaints included monotony, unfavourable working facilities, longer teaching hours than had been stated in the original contract, and unfulfilled promises of training or wages (Subbaravalu \& Al Kuwaiti, 2018).

With a heavy mixture of far too much teacher talk time and direct translations from native Arabic in order to lessen the load of teaching English, the majority of native Arab teachers delivering classes in English actually teach to the detriment of students' acquisition of communicative English language skills, with the target language rarely taught to an acceptable standard (Alfahadi, 2012). Added to this are the continual real-time grammatical and speech corrections, leaning less towards a communicative approach and more toward accuracy. Teaching to test is also commonplace as results are frequently not only target driven, but also unattainable due to unrealistic promises made by providers to college Deans (Pacino, 2016). There is also evidence to show that teachers can be prone to leaving the latest lesson delivery methods and theories at the classroom door and completely untried, while teaching strictly to the textbook (Pacino, 2016). Upper management has proved to be one of the main reasons that teachers stay in a post, though it is also one of the main reasons that they leave their jobs (Jones and Watson, 2017).

There are many challenges facing Saudi education institutions (Javid, 2014), among them are a lack of teacher preparation, poor quality facilities and a dearth of equipment and materials, although by the same token, many Saudi (nationals) teachers do not take up CPD programmes in the scientific field, and this may be indicative of Saudi teachers as a whole (Al Sharari, 2016). One reason for this is that some areas of teaching, science, for example, do not require specific certification before they are allowed to teach (Al Sharari, 2016). 


\begin{tabular}{|c|c|c|c|c|c|c|}
\hline \multirow{2}{*}{$\begin{array}{l}\text { Q No } \\
>\text { to }<\end{array}$} & \multirow{2}{*}{$\begin{array}{c}\text { Teachers' reasons for \& levels of (dis)satisfaction (institution) } \\
\text { Very dissatisfied, dissatisfied, no opinion, satisfied, very satisfied > }\end{array}$} & \multicolumn{5}{|c|}{ Current \% Job satisfaction } \\
\hline & & VDS & DS & No & $\mathbf{S}$ & VS \\
\hline 25 & Job security & 60 & 30 & 5 & 5 & 0 \\
\hline 26 & Short notice contract termination & 55 & 35 & 10 & 0 & 0 \\
\hline 50 & Syllabus and learners' level and needs & 65 & 20 & 5 & 10 & 0 \\
\hline 23 & Promises from the institution & 55 & 30 & 10 & 5 & 0 \\
\hline 35 & Assessment practices & 55 & 40 & 5 & 5 & 0 \\
\hline 37 & Teacher recognition & 45 & 40 & 15 & 0 & 0 \\
\hline 53 & Placement of students (proficiency and the classes they are placed) & 45 & 40 & 15 & 0 & 0 \\
\hline 36 & Easier exams for students & 50 & 30 & 15 & 5 & 0 \\
\hline 38 & Appreciation of teachers' hard work & 45 & 35 & 20 & 0 & 0 \\
\hline 21 & Resources and funding allocation & 55 & 15 & 25 & 5 & 0 \\
\hline 24 & Institution's competence & 60 & 10 & 20 & 10 & 0 \\
\hline 51 & Student absenteeism and attendance policy & 60 & 15 & 10 & 15 & 0 \\
\hline 52 & The students are able to keep up with the pacing guide. & 40 & 40 & 2 & 0 & 0 \\
\hline 60 & Treatent of teachers at work & 50 & 25 & 20 & 5 & 0 \\
\hline 48 & Culturally relevant teaching material and textbooks & 45 & 30 & 20 & 5 & 0 \\
\hline 27 & Teachers receive fair warning of contract loss & 40 & 35 & 20 & 5 & 0 \\
\hline 34 & Pay equality & 50 & 20 & 25 & 0 & 5 \\
\hline 39 & Visa issues & 55 & 10 & 25 & 10 & 0 \\
\hline 44 & The college's system for innovation or improvement & 45 & 25 & 20 & 10 & 0 \\
\hline 45 & Organisation's transparency in communication and what they try to achieve & 40 & 35 & 15 & 10 & 0 \\
\hline 49 & The company's spend on resources and facilities & 50 & 20 & 20 & 5 & 5 \\
\hline 59 & The work environment facilitates teaching & 40 & 35 & 15 & 10 & 0 \\
\hline 46 & Sufficient housing allowance/ accommodation problems & 50 & 10 & 30 & 10 & 0 \\
\hline 47 & Eeleventh hour culture & 50 & 25 & 5 & 15 & 5 \\
\hline 22 & Negative parental involvement & 50 & 20 & 10 & 10 & 10 \\
\hline 40 & Suitable/relevant curriculum & 30 & 40 & 15 & 15 & 5 \\
\hline 32 & Orientation for new teachers & 40 & 25 & 15 & 15 & 5 \\
\hline 29 & CPD opportunities & 40 & 10 & 30 & 20 & 0 \\
\hline 28 & Career progression, advancement or growth & 35 & 15 & 35 & 15 & 0 \\
\hline 56 & Technical training for teachers & 35 & 30 & 10 & 20 & 5 \\
\hline 57 & Facilities at work & 20 & 45 & 20 & 10 & 5 \\
\hline 30 & Integration procedure for new teachers & 45 & 40 & 5 & 15 & 15 \\
\hline 55 & Technology for teaching & 35 & 30 & 10 & 15 & 10 \\
\hline 58 & Working/functioning equipment & 40 & 25 & 5 & 15 & 15 \\
\hline 54 & Availability of resources & 15 & 40 & 30 & 15 & 0 \\
\hline 31 & Guidance or support for new teachers & 30 & 5 & 30 & 10 & 15 \\
\hline 33 & Living in KSA without family & 35 & 15 & 20 & 25 & 5 \\
\hline 41 & Salary & 40 & 10 & 15 & 30 & 5 \\
\hline 43 & Benefits like health insurance & 5 & 25 & 35 & 0 & 15 \\
\hline \multirow[t]{5}{*}{42} & Payment of salaries & 20 & 0 & 25 & 30 & 25 \\
\hline & possible score & 4000 & 4000 & 4000 & 4000 & 4000 \\
\hline & percentage of (dis)satisfaction of teacher & 43.375 & 25.125 & 17.5 & 10.125 & 3.625 \\
\hline & rounded figure for $\%$ of (dis)satisfaction of teacher & 43 & 25 & 18 & 10 & 4 \\
\hline & & VDS & DS & NO & $\mathrm{s}$ & VS \\
\hline
\end{tabular}

Fig 4. Institution job satisfaction responses (Pacino, 2016).

This leads to students suffering from a lack of enthusiasm for scholastic work, and while they miss classes, are continually late and have little yen to learn when they do turn up, these problems are exacerbated when added to the fact that many Saudi EFL teachers are habitually 
unprepared or improperly trained. Further problems include students' low proficiency in English language, a lack of interest in learning English, second language anxiety, over-crowded classes, and an almost complete lack of technological support (Javid, 2014). Given that English is not widely spoken outside the classroom, authentic environments are virtually non-existent and without this their progress is hampered. This makes attendance, punctuality and class work all the more important (Ashraf, 2018), though attendance rules are regularly and systematically flouted without recourse for the student (Pacino, 2016), which leaves many of them with an apathetic attitude towards their education and language learning.

The Saudi Government has been trying to revamp, revitalise and improve the curriculum for delivering English language since the early 1980s, however, one of the major sticking points seems to be the inability to separate the use of English language from the quirks of Saudi culture to be able to deliver successful classes while adhering to the strict conservative nature of the country (Alfahadi, 2012). As early as 2014 the Saudi Ministry of Education identified and attempted to address education as a priority. So much so that almost a quarter of the country's budget expenditure was spent on education in that year, when a number of new university campuses were built and hundreds of older institutions had major facelifts (Saudi Arabia Record Budget for 2015). And while there have been strides forward in recent years under the current leadership, there is no doubt that room for improvement still exists and needs addressing (Elyas \& Picard, 2018).

A further drawback for Saudi students has been that they receive little or no exposure to English until they get to high school age, which leaves them with weak English skills by the time they are at college or university level, highlighting the extremely high failure rate $(70 \%)$ of collegelevel students in English exams (Alfahadi, 2012). As there is so little interaction in English outside of the classroom setting, many teachers hold the belief that classes are simply not authentic enough, and until there is a more realistic context there will be little progress made on a grander scale (Khan, 2011; Hall, 2011; Shehdeh, 2012).

\section{Suggestions and possible further study}

In order to halt or even reverse this exodus, there has to be a shift in methods of delivery, more thorough and relative teacher training and professional development, and a genuine concern and adequate provision for the students and teachers. There must also be a smoother and more rigorous inauguration into the country and its culture for teachers in order that they fully understand the nature of the work, the students, the culture and the country they are going to commit themselves to. One glaring feature of this study is that there has been very little research conducted on both the demoralisation of teachers in this context and poor management, which might also shed further light on attrition rates and help halt the all too heavy turnover of EFL staff in the Kingdom.

As we have seen, motivation and job satisfaction are two of the most important factors for teachers staying in a post. Unless senior management recognise and address these points, the high teacher attrition rate is almost certain to continue. The many aspects of both management and the way an institute organises (or not) its training programmes, professional development regime and how it supports and treats its staff have a huge effect on how teachers develop trust in their management and feel secure in their posts. It is not only within the operation that teachers need support either. External factors such as families, visa issues, health matters and 
accommodation also affect a teacher's mind-set and their happiness with the company or the job, and contribute to teachers feeling that they are undervalued.

Recognising where problems arise and understanding how they can be addressed are vital for institutions to hold onto their talent and stem the drain that could stunt the growth and progress of pedagogy - and thereby the future talent - in the Kingdom. In order to do this, senior management must first look towards training themselves and other decision-makers, equipping their institutions with the appropriate sources and materials, and inducting their staff both culturally and professionally to the country.

\section{CONCLUSION AND SUGGESTION}

While there has been little expense spared in terms of funding Saudi's ambitious plan to deliver English language skills to larger swathes of the population, much of the plan seems to have fallen at the first couple of hurdles. Many factors that have caused this to happen; however, at the heart of the problem is that there is very little continuity in teaching due to large numbers of teachers exiting the Kingdom after a very short period of time. NEST attrition rates in Saudi Arabia are abnormally high due to a number of reasons; the most common being a serious lack of cultural training by management and/or provider, poor induction once a teacher arrives in country and culture. NNEST attrition rates are more aligned to professional reasons, as they feel they are treated poorly by comparison with their NEST counterparts: lower wages, fewer promotion opportunities, not being taken as seriously by students and employers, and sudden discontinuance of contracts among the main reasons for NNESTs leaving their posts. In order for the situation to improve, all of these factors have to be considered.

\section{CONFLICT OF INTEREST}

There are no conflicts of interest with this paper.

\section{FUNDING}

No funding was received to complete this research.

\section{REFERENCES}

Abdulkareem R. (2015) Proceedings 3rd regional conference on educational leadership and management. Differentiated supervision model: A way of improving school leadership in Saudi Arabia. In Proceedings $3^{\text {rd }}$ Regional Conference on Educational Leadership and Management. Institut Aminuddin Baki, 193-200.

Adelman, M. B., \& Lustig, M. W. (1981). Intercultural communication problems as perceived by

Saudi Arabian and American managers. International Journal of Intercultural Relations, 5(4), 349-363. doi: https://doi.org/10.1016/0147-1767(81)90047-X

Ahmad, H., Latada, F., Shah, R. R. \& Wahab, M. N. (2017). Exploring construction of professional selves of non-native EFL teachers at a Saudi Arabian University. Arab World English Journal. 8(4), 148-166. https://dx.doi.org/10.24093/awej/vol8no4.10

Al Asmari A. (2015). Communicative language teaching in EFL university context- Challenges for teachers. Journal of Language Teaching and Research. 6(5) 967-984. 
Albabtain, A. (2009). Difficulties faced by instructional supervisors in their work and how they overcome them. Journal of educational Psychological Sciences, 10(2), 239-268. https://doi.org/10.9790/0837-2411045562

Alfahadi, A. (2014). Saudi teachers' views on appropriate cultural models for EFL textbooks: Insights into TESO teachers' management of global cultural flows and local realities in their teaching worlds. [PhD submission], University of Exeter.

Alhammad, I. (2000). Barriers for instructional supervision in Riyadh schools, [unpublished thesis], King Saud University.

Alhamad, R. (2018). Challenges and induction needs of novice English as a foreign language teacher in Saudi Arabia. International; Journal of Education \&Literacy Studies. 6(1), 5063. https://doi.org/10.7575/aiac.ijels.v.6n.1p.50

Almakushi, A. (2003). Educational supervision: Definition and aims in theory and practice. Educational and Islamic Studies, 16(1), 263-294.

Alqahtani, Y. (2019). The impact of mentoring programs on new special education teachers' attrition in Saudi Arabia. Journal of Educational and Psychological Sciences. https://doi.org/10.13140/RG.2.2.26765.36326

Alsamdi, M. S., Qblan, Y. M., (2015). Assessment of job satisfaction among faculty members and its relationship with some variables in Najran University. Journal of Education and Practice. 6(35), 117-123.

Al Sharari, S. (2016). The challenges faced by new science teachers in Saudi Arabia. [PhD Thesis], West Virginia University.

Alzaidi, A.M. (2007). A qualitative study of job satisfaction among secondary school head teachers in the city of Jeddah, Saudi Arabia. ARCELS, 4, 1-15.

Ashraf, A. T. (2018). Teaching English as a Foreign Language in Saudi Arabia: Struggles and Strategies. International Journal of English Language Education, 6(1), 133-145. https://doi.org/10.5296/ijele.v6i1.13148

Bahanshal, D. A. (2013). The effect of large llasses on English teaching and learning in Saudi secondary schools. English Language Teaching, 6(11), https://doi.org/10.5539/elt.v6n11p49

Bhola, S. (2019) Faculty and administrator perceptions of the attrition of female expatriate ESL teachers' in Saudi Arabia [Doctoral thesis, Walden University]. https://scholarworks. waldenu.edu/cgi/viewcontent.cgi? article $=8643 \&$ context $=$ dissertatio $\underline{\mathrm{nS}}$

Borger, J. (2009, February 16). Saudi Arabia appoints first female minister. The Guardian. Guardian Newspapers. https://www.theguardian.com/world /2009/feb/16/saudi-cabinetwoman-minister

Brighton, C. M. (1999). Keeping good teachers: Lessons from novices. A better beginning: Supporting and mentoring new teachers, 197-201

Brittiler, M. C., \& Thabet, R. A. (2015). Predictors of job satisfaction of faculty members of Al Ghad International Colleges for Health Sciences. Asia Pacific Journal of Multidisciplinary Research, 3(2), 63-68. https://doi.org/10.1108/JARHE-07-2018-0128

Cooper, A. M. (1980). How you can speak Arabic as a well-spoken Arab would. The Christian Science Monitor. https://www.csmonitor.com/1980/0505/050503.html

Dörnyei, Z., \& Ushioda, E. (2011). Teaching and researching motivation (2nd ed.). Harlow, 
UK:

Longman

Elyas, T \& Picard, M. (2018). English as a foreign language in Saudi Arabia new insights into teaching and learning English. Routledge. https://doi.org/10.4324/9781315688466

Geiger, T. and Pivovarova, M. (2018) 'The effects of working conditions on teacher retention', Teachers and Teaching. Routledge, 24(6), 604-625. https://doi.org/10.1080/13540602.2018.145752

Hall, G. (2011). Exploring English language teaching. Language in Action. Taylor \& Francis Group. Routledge.

Hanneman, J. M. (2014). We can't keep giving: An analysis of the prevalence and consequence of educators' unpaid labor [Doctoral dissertation]. https://academicworks.cuny.edu

Hattie, J. (2005). The paradox of reducing class size and improving learning outcomes.

International Journal of Educational Research, 43, 387-425. https://doi.org/10.1016/j.ijer.2006.07.002

Heppner, F. (2007). Teaching the large college class. Jossey-Bass

Hughes, G. D. (2012) 'Teacher retention: Teacher characteristics, school characteristics, organizational characteristics, and teacher efficacy', The Journal of Educational Research. Taylor \& Francis Group, 105(4), 245-255. https://doi.org/10.1080/00220671.2011.584922.

Jamjoom, Y. (2012). Understanding private higher education in Saudi Arabia: Emergence, development and perceptions. Institute of Education, [Unpublished $\mathrm{Ph}$. D. thesis], University of London.

Javid, C.Z. (2014). Measuring language anxiety in an EFL context. Journal of Education and Practice. 5, (25) 180-193.

Jones, D. and Watson, S. B. (2017) 'The Relationship Between Administrative Leadership Behaviors and Teacher Retention in Christian Schools', Journal of Research on Christian Education. https://doi.org//10.1080/10656219.2017.1282903

Khan, I. (2012). Relevance of teacher development: The EFL context of KSA. Procedia-Social and Behavioural Sciences, 47, 756-764. https://doi.org/10.1016/j.sbspro.2012.06.730

Louber, I. (2015). The global spread of English and the teaching of English as a foreign language:

Perspectives from western Muslim teachers of English as a foreign language in the Kingdom of Saudi Arabia. [Doctoral thesis], Exeter University.

Mansour, N., Alsamrani, S. M., Aldahmash, A. H. \& Alqudah, B. M. (2013). Saudi Arabian teachers and supervisors' views of professional development needs. Egitim Arastirmalari-Eurasion Journal of Educational Research. 51, 29-44.

Mansory, M. (2019). The Meaning and Practice of Professionalism of EFL Teachers in the Saudi

Context. English language teaching; 12(1), 194-203. https://doi.org/10.5539/elt.v12n1p194

Miley, C. (2013). Saudi Arabia permits first women lawyers to practice law. Jurist. http://jurist.org/paperchase/2013/10/saudi-arabia-permits-first-women-lawyers-topractice-law.php

Mosadegh, M R, A., \& Yarmohammadian, H, M. (2006). A study of relationship between 
managers' leadership style and employees' job satisfaction. Leadership in Health Services, 19(2), 11-28. https://doi.org/10.1108/13660750610665008

Nolan, L. (2012). Liberalizing Monarchies? How Gulf Monarchies Manage Education Reform.

Brookings. https://www.brookings.edu/research/liberalizing-monarchies-how-gulfmonarchies-manage-education-reform/

Omar, S. (2016). Concerns and professional development needs of faculty at King Saud University in Saudi Arabia in adopting online teaching. [Doctoral thesis] Kansas State University.

Pacino, A. (2016). The challenges of teaching English as a foreign language in Saudi Arabian colleges with a focus on teacher motivation. [Unpublished master's thesis]. Lancaster University.

Pedder, D. (2006). Are small classes better? Understanding relationships between class size, classroom processes and pupils' learning. Oxford Review of Education, 32(2), 213-234. https://doi.org/10.1080/03054980600645396

Periansya, Z. (2017). Determinants of job satisfaction and its implication on the performance of public universities lecturers in South Sumatera. Research Reviews: Journal of Social Sciences, 3(1), 49-63.

Samuel, M. O. \& Chipunza, C. (2013). Attrition and retention of senior academics at institutions of higher learning in South Africa: The strategies, complexities and realities. Journal of Social Sciences, 35(2), 97-109. https://doi.org/10.1080/09718923.2013.11893151

Saudi Arabia - Record budget for 2015. (2015, January 5). gov.uk. https://www.gov.uk/government/publications/saudi-arabia-record-budget-for2015/saudi-arabia-record-budget-for-2015

Shah, S., Hussein, M. \& Nasseef, O. (2013). Factors impacting EFL teaching: An exploratory study in the Saudi Arabian context. Arab World English Journal, 4(3), 104-123.

Shannag, Q.A., Tairab, H., Dodeen, H., \& Faisal, A.F. (2013). Linking teachers 'quality and student achievement in the Kingdom of Saudi Arabia and Singapore: The impact of teachers' background variables on student achievement. Journal of Baltic Science Education, 12 (5), 652-665.

Shehdeh, F. (2010). Challenges of teaching English in the Arab world: Why can't EFL programs

deliver as expected? [online] Available at: ipac.kacst.edu.sa/eDoc/2011/195630-1.pdf

Stainton, H. (2017). TEFL tourism - The tourist who teaches. Tourism geographies. 20(1) 127143 https://doi.org/10.1080/14616688.2017.1298151

Subbarayalu, A. V., \& Al Kuwaiti, A. (2018). Quality of work life of teaching staff working at a higher education institution in Saudi Arabia: A cross-sectional study. Journal of Social Service Research, 1-13. https://doi.org/10.1080/01488376.2018.1481173

Topal. A. (2019). Economic reforms and women's empowerment in Saudi Arabia. Women's Studies International Forum, 76, 102253. https://doi.org/10.1016/j.wsif.2019.102253 .pdf

Tshannen-Moran, M., Woolfolk-Hoy, A. \& Hoy, W. (1998). Teacher efficacy: Its meaning and Measure. Review of Educational Research, 68, 202-248. https://doi.org/10.3102/00346543068002202

Yusuf, N. (2014). Delivering long-term sustainable growth through investment in young people 
- Saudi Arabia. International Journal of Business and Economic Development 2(3), 96108. https://ijbed.org/cdn/article_file/i-6_c-68.pdf 